\title{
SPATIO-TEMPORAL VARIATIONS OF WIND SPEED DURING HARMATTAN SEASON IN NORTHEASTERN NIGERIA
}

\author{
Dantata Danlami ${ }^{1}$, Saidu Idris ${ }^{1}$, Richard Sunday Thlakma ${ }^{1}$ and Golly Sammy Gwandum ${ }^{2}$ \\ ${ }^{1}$ Department of Geography Faculty of Humanities, Management and Social Sciences Federal \\ University of Kashere, PMB 0182 Gombe State, Nigeria. \\ ${ }^{2}$ Department of Mathematics, College of education P.M.B 011 Billiri, Gombe State Nigeria
}

Received 30 January 2019/ Revised 4 July 2019/ Accepted 15 July 2019/ Published 2 August 2019

\begin{abstract}
Wind speed is the principal climatic element that drives the Marmaton season in West African sub region. It drives the season by conveying huge amount of dust across the Northeastern Nigeria. The presence of dust in the atmosphere brought by the Northeast trade winds during the Harmattan season plays a vital role in absorbing and scattering solar radiation. The study examines the spatial and temporal variations of wind speed in Northeastern Nigeria during the Harmattan season with the sole aim of ascertaining its variability, patterns and trends from 1984 to 2014. Descriptive and statistics such as mean, standard deviation, coefficient of variation, and time series analysis with ArcGIS 10.3 was used in examine the temporal and spatial variations of wind speed from 1984-2014 in six synoptic stations of Northeastern Nigeria. The findings show that wind speed varied both temporally and spatially in the last three decades. The pattern of variations in the six synoptic stations shows rising trends within the study years. It was also found that latitude playing a crucial role in determining the speed of the wind in the study area and as the speed of the wind increases with increasing latitude.
\end{abstract}

Keywords: Wind speed, Harmattan, Season, Northeast, Variation and ITD.

\section{Introduction}

Wind speed is the principal driver of the Harmattan season in West African Sub region. It is the Northeast trade wind that seasonally conveys huge amount of dust across the region that produces the Harmattan season between November and December of one year and January, February and March of the subsequent year (Danlami, 2017). Wind speed which is translated as its capacity for rapid motion plays a very remarkable role in influencing the Harmattan season variations in northeastern Nigeria. It is important to note that, the variation in wind speed distribution is also important with respect to the impacts of climate variability and change (Karabulut al.,2012) and (Amadiet al.,2014). Wind as an element of climate always moves from 
area of high pressure to area of low pressure system. The movement of the wind in the first place is determined by pressure gradient in the Sahara Desert during the period of the low sun (winter period in the Northern hemisphere) and the greater the pressure of the air, the faster the wind moves. There is no gainsaying that the speed of the wind determines the amount of dust that is seasonally or annually brought into the region. Therefore, assessing the speed at which this climatic parameter moves across the study area during Harmattan season will go a long way in making sense out of its Spatio-temporal variations in last three decades.

Wind speed is an environmental resource that facilitate the generation of wind energy. Due to recent development in wind energy mostly in developed countries (especially in Europe) with desire to reduce environmental impacts of the conventional energy resources, there is a general growing interest in the wind energy development in Nigeria (Adaramola and Oyewola 2011). It is against this background this research examines the Spatio-temporal variations of wind speed during Harmattan season in Northeastern Nigeria by assessing its variability, patterns and trends from 1984 to 2014.The Northeast trade wind controls the Harmattan season in West African sub region; it drives the season by conveying huge amount of dust across the region (Danlami, 2017). This wind advances into the savannah belts of Nigeria due to the seasonal migrations of the Inter-Tropical Discontinuity (ITD). The ITD attains its southernmost position around latitude $6^{0} .00^{1} \mathrm{~N}$ in January. This marks the peak of the dry season in West Africa with all the areas with the exception of the coastal areas under the influence of the dry Northeasterly from the Sahara Desert (Ayoade, 2004). The North east trade wind commonly referred to as the Harmattan wind; arise due to synoptic-scale of pressure gradients that align north-south across the Saharan desert.

High pressure to the north of the Bodele intensifies the NE trade winds, leading to an increased entrainment of dust in the Bodele Depression. In summer, dust mobilization cannot be explained by the large scale meteorological conditions. This highlights the importance of local to regional wind systems linked to the northernmost position of the inter-tropical convergence zone (ITCZ) during this time (Schwanghart and Schutt, 2007).Harmattan season is highly dependent on air pressure variability in the Mediterranean area (Schwanghart and Schutt, 2007). When the northeast trade wind covers substantial parts of West African countries towards the coast and that is when the dry season is experienced. During the months of November and December to the months of January, February and March, the climate of the West African region is dominated by 
northeasterly trade winds. The subtropical pressure belt system over North Africa near latitude $30^{0}$ north is responsible for the movement of the NE trade wind. The deflecting force of the earth's rotation known as the corilis force is responsible for the Northeast direction of this trade wind. Winds are caused by pressure differences that induce airflow from zones of high pressure to zones of low pressure (Getis el at., 2011). In other words, wind originates from region of high pressure belt and move to the region of low pressure belt. This trade wind that originates from the subtropical high pressure belt in the northern hemisphere plays a key role in influencing the climate of West Africa. It is this wind that blows and pick up fine dust and sand particles otherwise known as crustal materials from the Sahara Desert and produce the Harmattan season across West African sub region.

\section{The Methods}

The study area in this article is Northeastern Nigeria. It comprises Adamawa, Bauchi, Borno, Gombe and Yobe states. It is approximately located between latitudes $9^{0} 30^{1} \mathrm{~N}$ and $14^{0} .00^{1} \mathrm{~N}$ and longitudes $9{ }^{0} 14^{1} \mathrm{E}$ and $15^{0} .00^{1} \mathrm{~N}$. It shares border with Niger Republic to the North, Lake Chad to the North-east, and Cameroon Republic to the East. Plateau and Taraba states to the South and Jigawa state to the West. The locations of the synoptic stations can be seen in table 1.

Table 1. Locations of the Six Synoptic Stations in the study area

\begin{tabular}{ccccc} 
S/No & $\begin{array}{c}\text { Synoptic } \\
\text { Stations }\end{array}$ & $\begin{array}{c}\text { Latitude } \\
\left({ }^{0} \mathrm{~N}\right)\end{array}$ & $\begin{array}{c}\text { Longitude } \\
\left({ }^{0} \mathrm{E}\right)\end{array}$ & $\begin{array}{c}\text { Elevation } \\
(\mathrm{m})\end{array}$ \\
\hline 1 & Bauchi & $10^{0} 28^{\prime}$ & $09^{0} 50^{\prime}$ & $616 \mathrm{~m}$ \\
2 & Gombe & $10^{0} 27^{\prime}$ & $11^{0} 10^{\prime}$ & $449 \mathrm{~m}$ \\
3 & Maiduguri & $11^{0} 27^{\prime}$ & $13^{0} 09^{\prime}$ & $300 \mathrm{~m}$ \\
4 & Nguru & $12^{0} 88^{\prime}$ & $10^{0} 29^{\prime}$ & $321 \mathrm{~m}$ \\
5 & Potiskum & $11^{0} 70^{\prime}$ & $11^{0} 04^{\prime}$ & $475 \mathrm{~m}$ \\
6 & Yola & $09^{0} 23^{\prime}$ & $12^{0} 27^{\prime}$ & $163 \mathrm{~m}$ \\
\hline
\end{tabular}

Source: Danlami (2017)

The table above represents the six synoptic stations spread across Northeastern Nigeria where climatic data are generated by the Nigerian Meteorological Agency (NIMET). The data shows the locations and elevations of the synoptic stations in the five states of Northeastern 
Nigeria. The Bauchi station in Bauchi state, Gombe station in Gombe state, Maiduguri station in Borno state, Nguru and Potiskum stations in Yobe state, and Yola station in Adamawa state. From the table, it is glaring that Bauchi station has the highest elevation in the Western part of the study area and Yola station with the lowest elevation in the Southern part of the study area

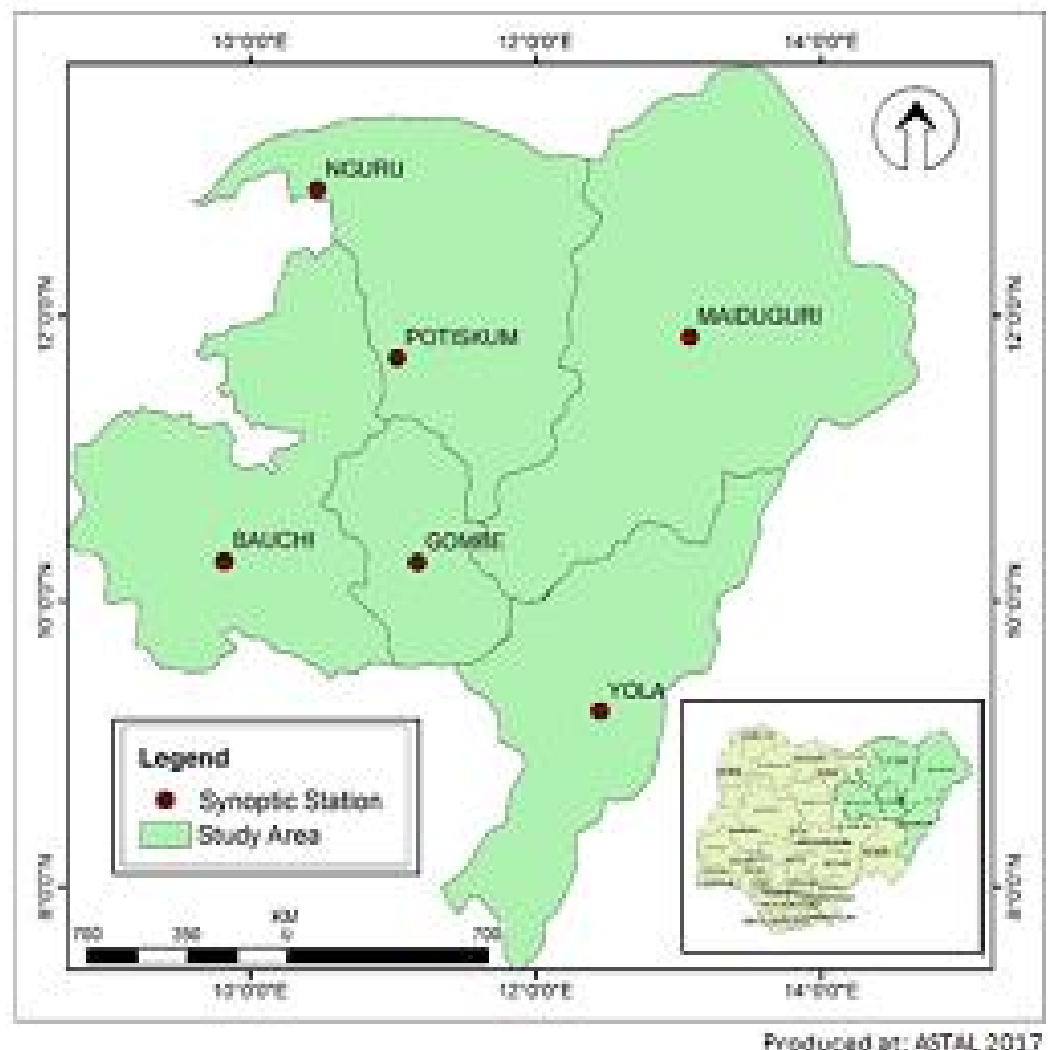

Figure 1. Study Area Source: Danlami, (2017)

The Meteorological data used for the trend-surface analysis in this study was obtained from the Nigerian Meteorological Agency (NIMET). The quantitative data covered a period of 30 years $(1984-2014)$. In an attempt to analyze the temporal variations and trends of wind speed in the six synoptic stations (Bauchi, Gombe, Maiduguri, Nguru, Potiskum and Yola) in the study area, mean monthly and mean seasonal data were plotted for each station so as to depict the variations and trends in the last three decades.

\section{Results and Discussion}

The raw wind speed data was subjected to the statistical tools of Mean, Standard Deviation, Coefficient of Variation; Time Series through the use of the statistical package for the 
Dantata Danlami, et al/ GEOSI Vol. 4 No. 2 (2019) 105-123

social sciences (SPSS) to show the variations and trends of wind speedin the last three decades. Also, the study mapped out the spatial patterns over the six different synoptic stations to observe the spatial patterns over time in the ArcGIS 10.3 environment. The trend equations were also superimposed on the seasonal mean variations of each synoptic station so as to establish their trends over the years in the study area.The trends and variations of wind speed in all the six synoptic stations of the study area were determined by their monthly and seasonal means in the last three decades. The Figures 1.2 to 1.8 show clearly the variations in wind speed in all synoptic stations of the study area. It is also glaring from the figures (1.3 to 1.8) that the speed of wind diminishes as it travels southward across the study area. Danlami et al (2018) pointed out that the Biu plateau is the most important geomorphologic formation in the study area and the strategic location of the Biu plateau on the path of the Harmattan wind is responsible for the reduction in the speed of the wind thus reducing the amount of dust reaching the extreme south of the study area resulting to moderate visibility in areas around Yolastation. They opined that the Plateau is a structural and topographical divide between the Upper Benue Basin to the south and the Chad Basin to the north.

\subsection{Monthly Distribution of Wind Speed}

The speed of the Northeast trade wind that brings the Harmattan dust from the Sahara Desert and engulfs the whole of West African sub region varies with time and across space. There are slight variations in the speed of wind during the five (5) months of the Harmattan season. The speed of the wind is higher at the source region and decreases as it advances towards the Gulf of Guinea in the South. The validity of this statement can be seen in the sizes of dust particles that are blown by the wind. Larger dust particles are usually dropped along the way and the finer particles are moved further down south (De Longueville et al., 2010). This is because at the dust source region, the high velocity of the wind could carry larger dust particles but as the wind grows weak in the course of its journey down south, the larger dust particles are dropped and finer ones are moved further into the Gulf of Guinea and beyond. The speed of the wind therefore, decreases with increase in distance (space) from its source. The wind speed variations can be clearly seen on (Fig. 1.2) across the six synoptic stations of the study area. Yola station that is located in lowest latitude has the lowest wind speed with long-term monthly mean between 1.00 to 2.00 Knots. Maiduguri and Potiskum stations with the highest mean monthly 
wind speed between 5.00 to 6.00 Knots. Gombe, Bauchi and Nguru fall between 3.00 to 5.00 Knots during the Harmattan season. The mean monthly wind speeds for the whole stations fluctuate between 2.00 to 7.00 Knots throughout the Harmattan seasons (November, December, January, February and March) in the study area. Wind speed is measured in Knot in which one knot of wind speed is equal to one nautical mile or one thousand eight hundred and fifty-two meters $(1852 \mathrm{~m})$ per hour. The International Organization of standardization (ISO) standard symbol for knot is Kn.

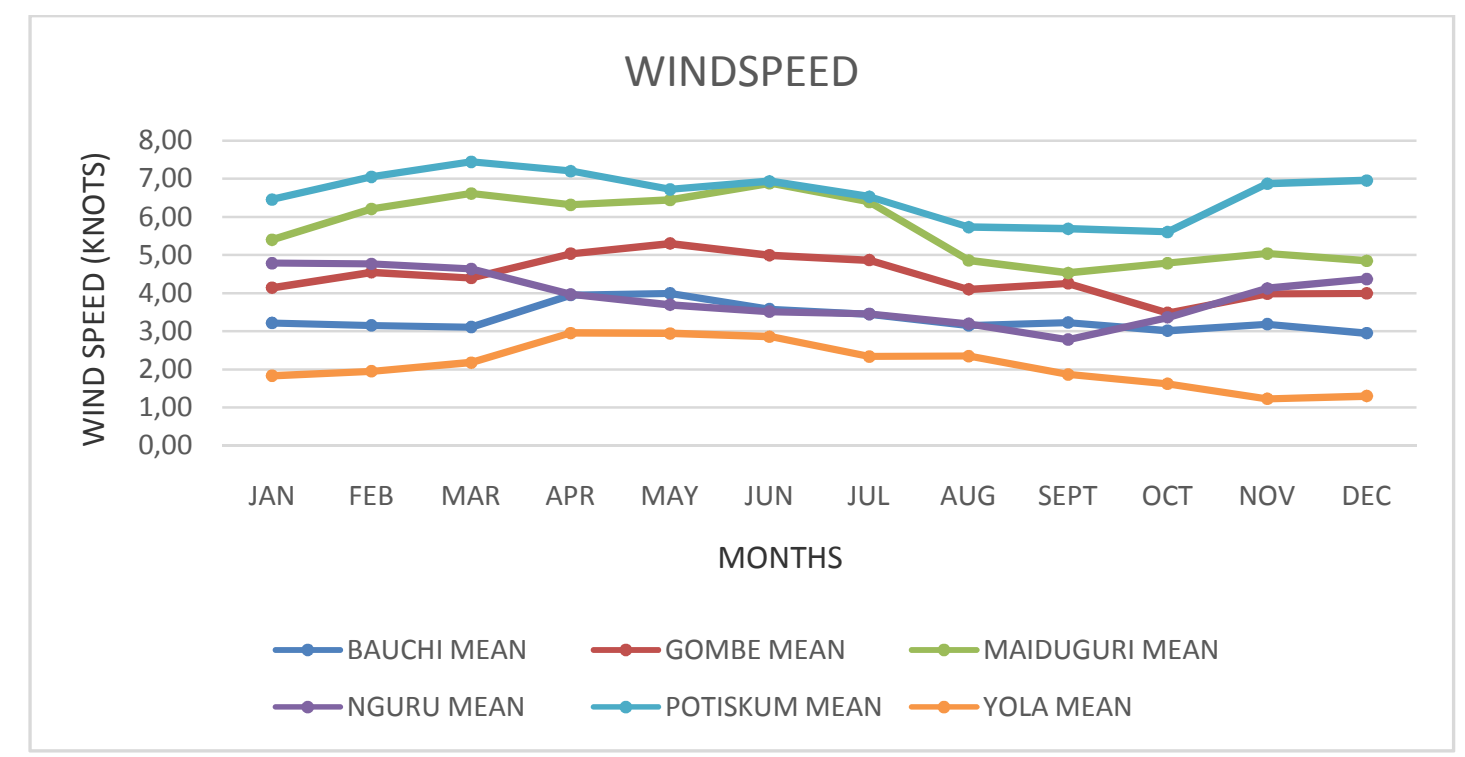

Figure 2. Long-Term means monthly Distribution of wind speed (1984 to 2014)

\subsection{Seasonal Mean Distribution of Wind Speed}

The Northeast trade wind is the driver of the Harmattan season across West Africa. It drives the season by conveying huge amount of dust into the atmosphere across West African sub region and beyond. The Northeast trade wind that advances into the savannah belts of Nigeria due to the sudden migration of the Inter-Tropical Discontinuity (ITD) southwards in between October and November remains the dominant wind system during the Harmattan season in the study area. It is interesting to note that the subtropical high pressure system is usually strong during the Harmattan season and it intensifies the movement of the wind which inevitably accounts for rising of the dust over the source regions (Bodele Depression) in the Sahara Desert for onward movement across West Africa and beyond. The speed of the wind therefore, determines the amount of dust it carries into the atmosphere. 
Dantata Danlami, et al/ GEOSI Vol. 4 No. 2 (2019) 105-123

Table 2 shows the influence of latitude and some other local geographical factors that affect the seasonal means distribution of wind speed and coefficient of variations.

Table 2. Descriptive Statistics of Seasonal Wind Speed and Coefficient of Variation Mean

\begin{tabular}{clllll} 
S/NO & Stations & $\begin{array}{c}\text { Latitude(Y) } \\
\left({ }^{0} \mathrm{~N}\right)\end{array}$ & $\begin{array}{c}\text { Seasonal } \\
\text { Wind } \\
\text { Speed } \\
\text { (knots) }\end{array}$ & $\begin{array}{c}\text { Standard } \\
\text { Deviation }\end{array}$ & $\begin{array}{c}\mathrm{CV} \\
(\%)\end{array}$ \\
\hline 1 & Bauchi & 10.28 & 3.07 & 1.72 & 56.08 \\
\hline 2 & Maiduguri & 11.85 & 5.67 & 0.69 & 12.24 \\
\hline 3 & Gombe & 10.27 & 4.21 & 2.16 & 51.21 \\
\hline 4 & Nguru & 12.88 & 4.56 & 0.43 & 9.40 \\
\hline 5 & Potiskum & 11.70 & 7.08 & 2.11 & 29.86 \\
\hline 6 & Yola & 9.23 & 1.68 & 0.22 & 12.84
\end{tabular}

Source: Danlami (2017)

Generally, wind speed is relatively low during the Harmattan season. It is in the range of $5 \mathrm{kn}$ to $20 \mathrm{kn}$ in Northern Nigeria and $5 \mathrm{kn}$ to $15 \mathrm{kn}$ in Southern Nigeria (NIMET, 2014). The study has found out that wind speed ranges from $1 \mathrm{kn}$ to $12 \mathrm{kn}$ across the six synoptic stations (Fig. 1.3 to 1.8 ) of the study area.

The seasonal means distribution of wind speed in Bauchi recorded its lowest in 2003/2004 and the highest in two seasons (2009/2010 and 2010/2011). Gombe recorded its lowest wind speed in 1994/1995 and the highest in 2003/2004; Maiduguri recorded the lowest wind speed in 1998/1999 and the highest in 2010/2011; Nguru recorded the lowest wind speed in 1986/1987 and the highest in 1992/1993; Potiskum recorded the lowest wind speed in 1984/1985 and the highest in 1993/1994 and Yola recorded the lowest wind speed in 1995/1996 and the highest in 2005/2006. The seasonal means distribution of wind speed in all the synoptic stations in the study area have shown the fluctuating characteristics of the wind speed in all the synoptic stations. The oscillations of the distributions depict most of stationsdominated by the below 
means which are clear indications that the study area is experiencing gradual reduction in the speed of the wind. Although all the synoptic stations have shown rising trends; in recent times the distributions in all stations have shown declining patterns and this may not be unconnected with the environmental education and awareness through tree planting campaign as shelter belts to serve as wind breakers by countries within the Sudano-sahelian ecological zones. The United Nations Conference on Desertification that came up with "Plan of Action to Combat Desertification" has demonstrated great deal of support in promoting and coordinating the plan of action to combat desertification in North Africa.

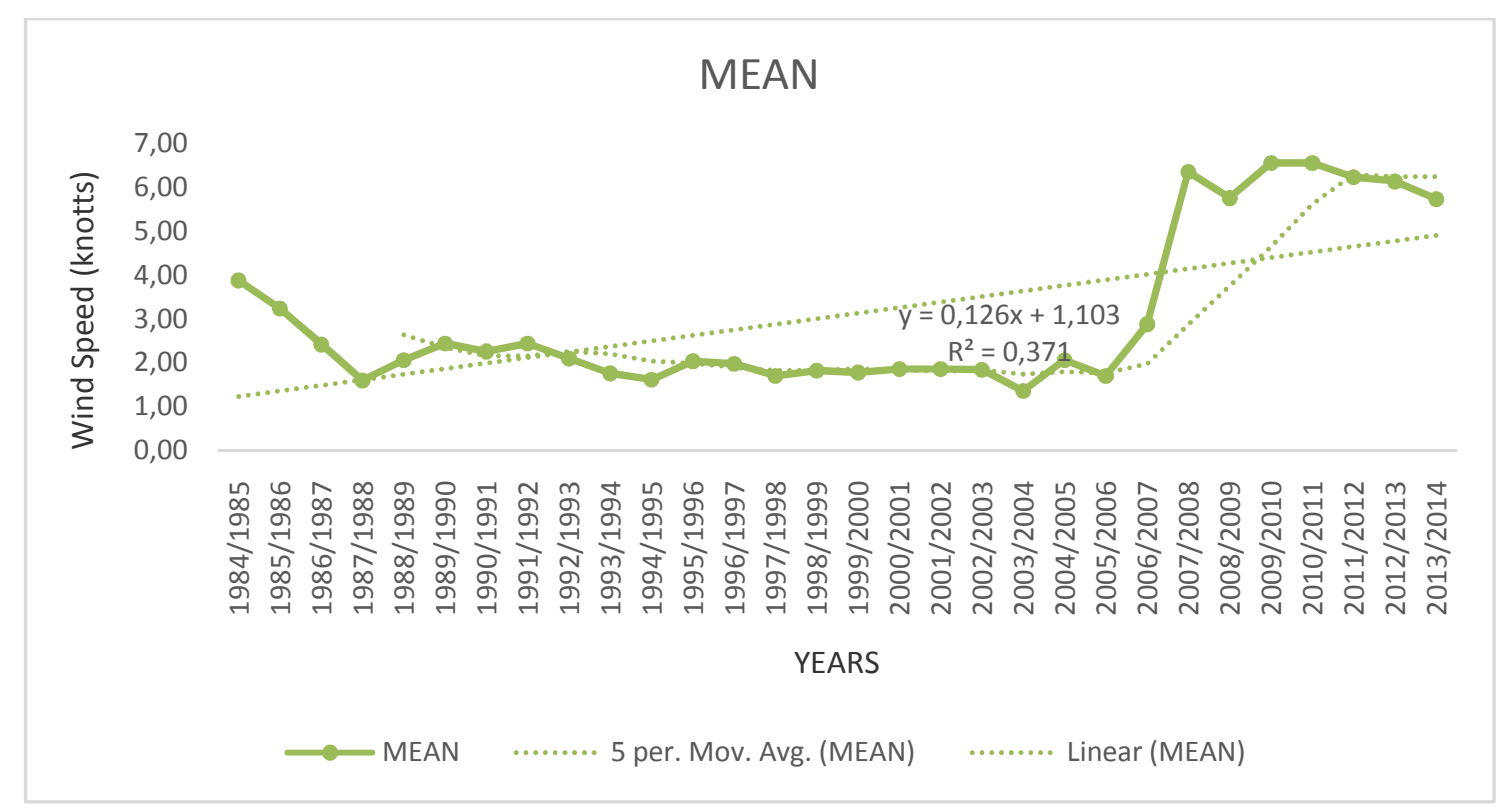

Figure 3. Seasonal mean Distributions and Trend of Wind Speed for Bauchi station (1984 to 2014)

The seasonal mean distribution above shows the trend of wind speed for Bauchi station from 1984 - 2014. The mean monthly wind speed is between 1.36kn recorded in 2003/2004 Harmattan season and 5.56kn recorded in 2010/2011 and in 2011/2012 Harmattan seasons. This Fig. 1.3 shows pattern of oscillation around the linear mean where the above average wind speed coincides with the below average. It portrays the inter-annual variation of wind speed in the last thirty (30) years. 
Dantata Danlami, et al/ GEOSI Vol. 4 No. 2 (2019) 105-123

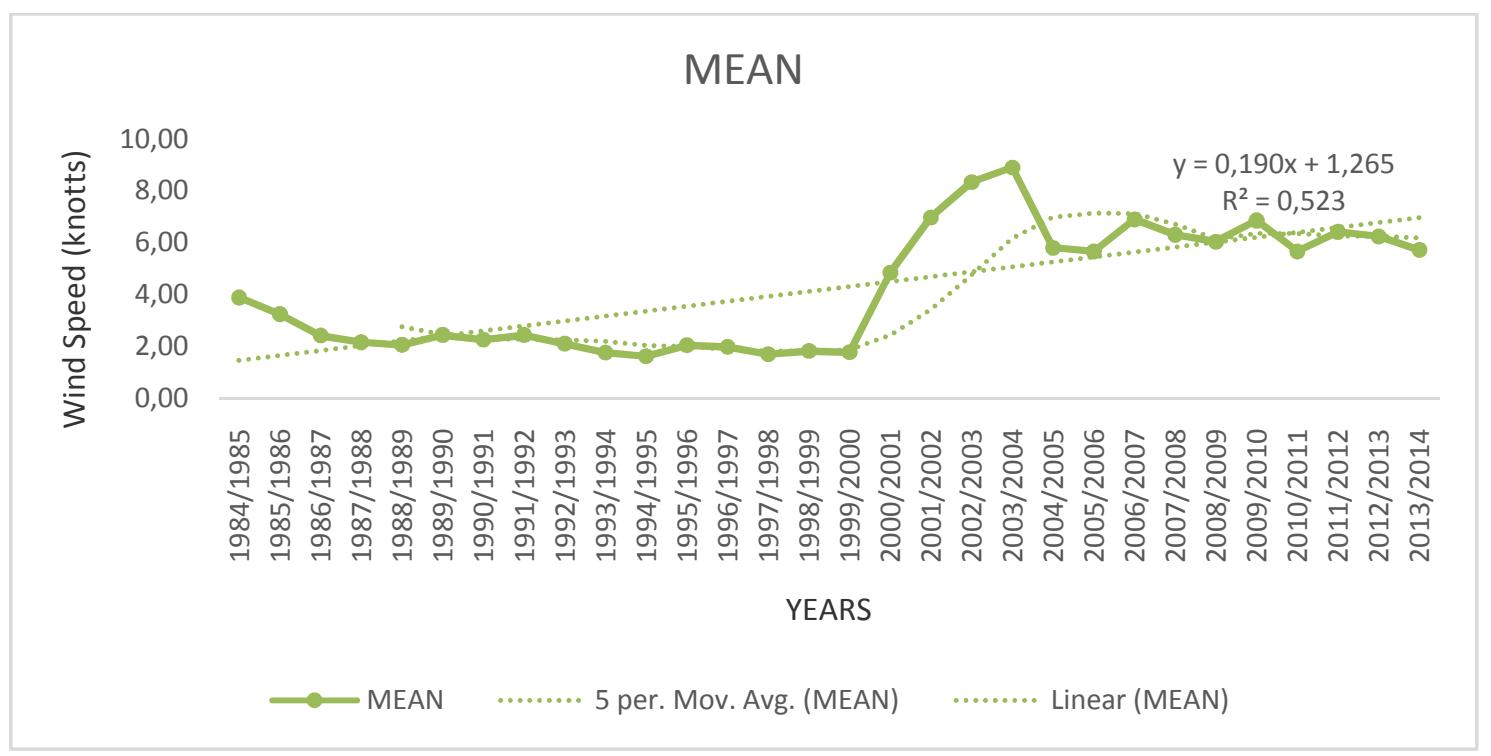

Figure 4. Seasonal Mean Distributions and Trend of Wind Speed for Gombe station (1984-2014)

The seasonal mean distribution shows the trend of wind speed for Gombe station from 1984 - 2014.The mean monthly wind speed is between $1.62 \mathrm{kn}$ recorded in 1993/1994 season and $8.34 \mathrm{kn}$ recorded in 2003/2004 Harmattan season. It shows the pattern of movement around the mean where the above average wind speed coincides with the below average. It portrays the inter - seasonal variation within the period under review.

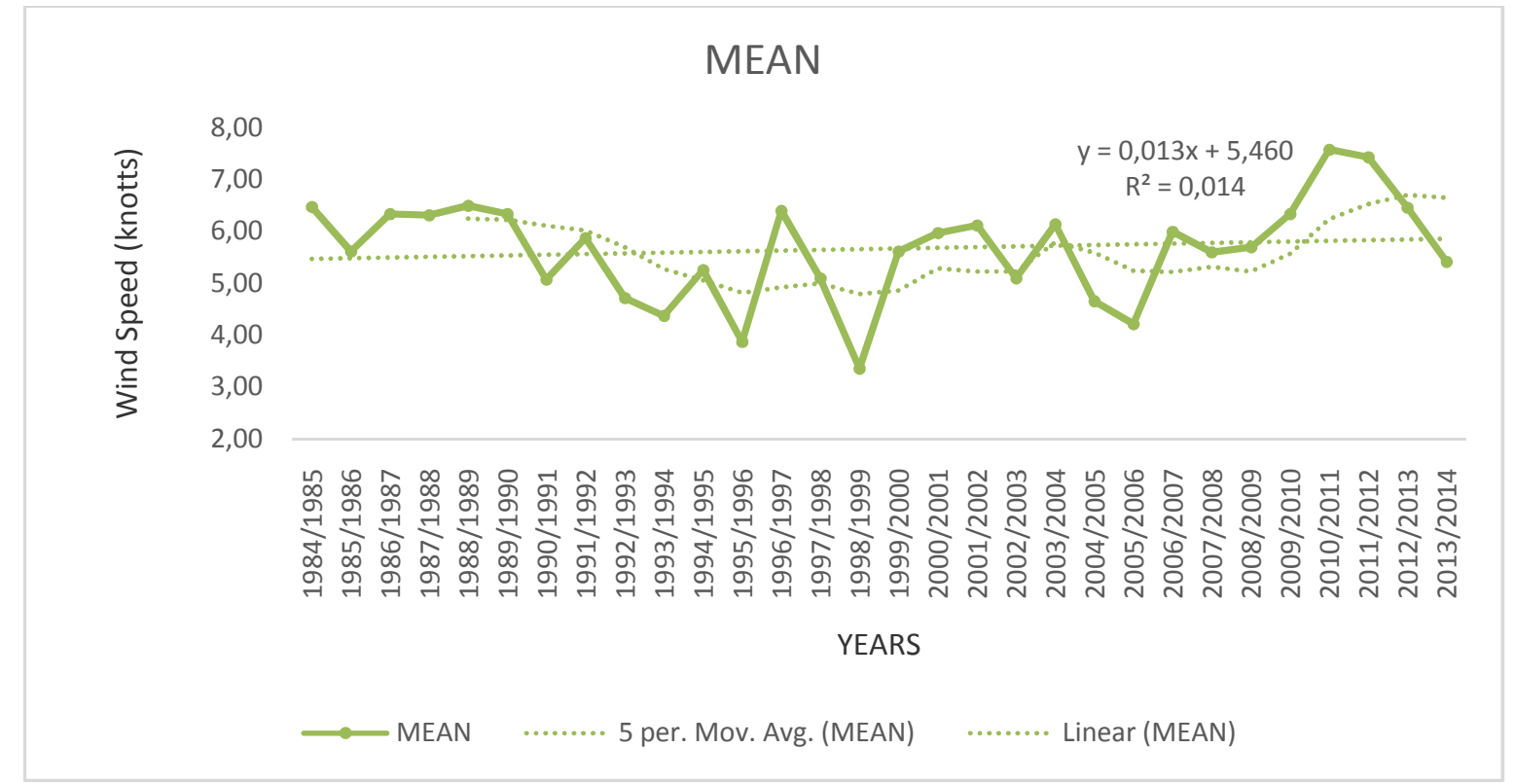

Figure 5. Seasonal Mean Distributions and Trend of Wind Speed for Maiduguri station (19842014) 
The seasonal mean distribution shows the trend of wind speed for Maiduguri station from 1984 - 2014. The mean monthly is between 3.36kn recorded in 1998/ 1999 season and $7.58 \mathrm{kn}$ in 2010/2011. The Fig. 1.5 shows pattern of oscillation around the mean where the above average wind speed coincides with the below average. It shows the inter-seasonal variation within the last thirty (30) years.

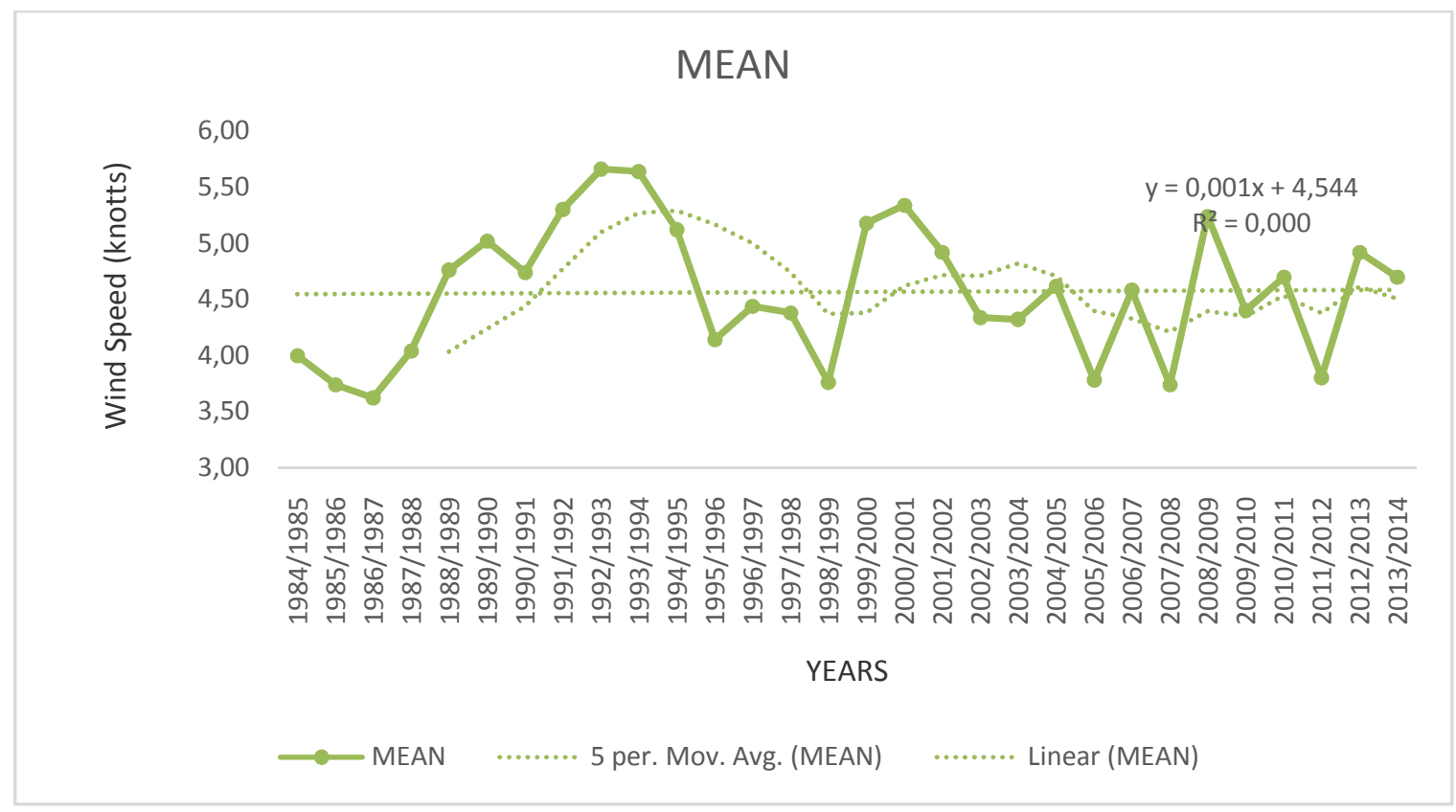

Figure 6. Seasonal Mean Distributions and Trend of Wind Speed for Nguru station (1984 to 2014)

The seasonal mean distribution shows the trend of wind speed for Nguru station from 1984 - 2014. The mean monthly win wind speed is between $3.62 \mathrm{kn}$ recorded in $1986 / 1987$ season and 5.66kn in 1992/1993 season. The fig. 1.6 shows the pattern movement of the seasonal mean where the above average coincides with the below average. This shows the inter - annual variation of wind speed within the period under review. 
Dantata Danlami, et al/ GEOSI Vol. 4 No. 2 (2019) 105-123

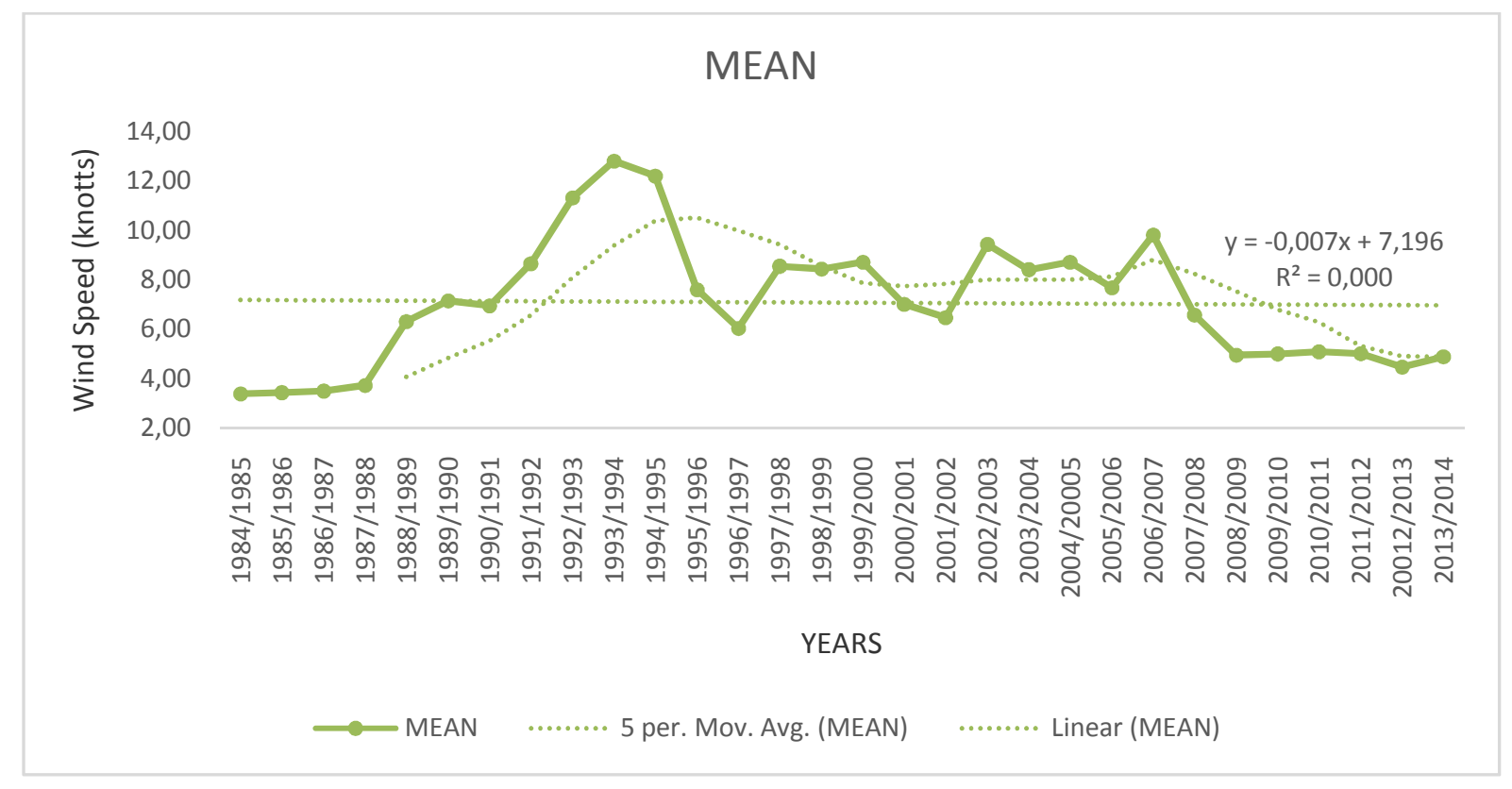

Figure 7. Seasonal Mean Distributions and trend of Wind Speed for Potiskum station (19842014)

The seasonal mean distribution shows the trend of wind speed for potiskum from 1984 2014. The monthly mean for this station shows between $4.48 \mathrm{kn}$ in 2012/2013 season and $9.42 \mathrm{kn}$ in 2002/2003 season. It depicts the pattern of movement where the above average coincides with the below average which portrays the inter - annual variation of wind speed within the period under review. 
Dantata Danlami, et al/ GEOSI Vol. 4 No. 2 (2019) 105-123

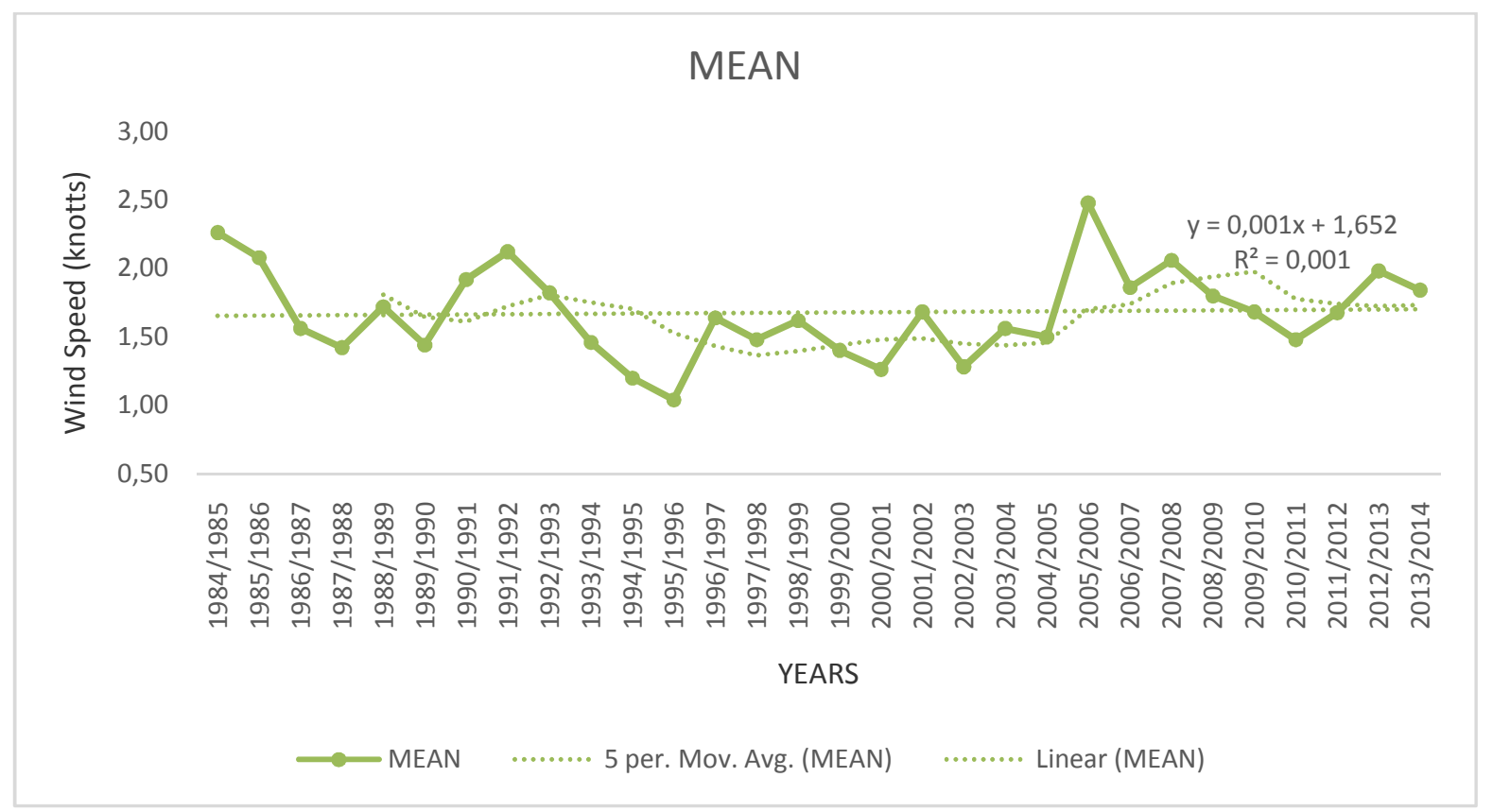

Figure 8. Seasonal Mean Distributions and Trend of Wind Speed for Yola station (1984-2014).

The seasonal mean distribution shows trend of wind speed for Yola station from 1984 2014. The mean monthly distribution is between $1.00 \mathrm{kn}$ in $1995 / 1996$ Harmattan season and $2.48 \mathrm{kn}$ in 2005/2006 season. The station shows a pattern of oscillation around the mean where the above average coincides with the below average. This Fig. 1.8 shows a decreasing speed of the wind because it is located at extreme southern part of the study area. This conforms withthe theory that states that the speed of the Harmattan wind decreases southward. It shows the inter annual variation of the speed of the wind within the last thirty (30) years.

\subsection{Spatial Interpolation of Sub Periods Mean of Wind Speed}

The surface visibility degradation experienced in the study area is caused by the arrival of the dust brought by the north east trade wind from the Bodele depression at the heart of the Sahara Desert (Danlami et al 2018). The arrival of this dust that usually engulfs the region is the most conspicuous sign of Harmattan season and therefore, responsible for the degraded visibility. Harmattan season low visibility is mainly due to transported dust from the Sahara (Balarabe et al., 2015). An attempt was made to look at the spatial interpolation of sub period means of surface visibility distribution in the study area with the sole aim of assessing the patterns of the distribution. Kriging method of spatial interpolation was employed in this analysis so as to 
determine the spatial variations of visibility in the study area. Kriging is a geostatistical technique similar to IDW in that it uses a linear combination of weights at known points is used to estimate values at other unknown points (Willmott et al., 1985; Shuman, 2007). Kriging and IDW methods have been often used to interpolate temperature and precipitation (Su-na et al., 2010). IDW measures values closest to the prediction location which will have the greatest influence on the predicted values than those farther away (Johnston et al., 2001).

The Northeast trade wind that seasonally conveys huge amount of dust across the West African sub region that produces the Harmattan season between November and December of one year and January, February and March of the subsequent year (Danlami, 2017) plays a crucial role in regulating the climatic condition of the region. Wind speed which is translated as its capacity for rapid motion, plays a very remarkable role in influencing the Harmattan season variations in northeastern Nigeria. It is important to note that, the variation in wind speed distribution is also important with respect to the impacts of climate variability and change (Karabulut al.,2012; Amadiet al.,2014).

The movement of the wind in the first place is determined by pressure gradient in the Sahara Desert during the period of the low sun (winter period in the Northern hemisphere). The greater the pressure of the air, the faster the wind moves from the region of high pressure to the region of low pressure system. There is therefore, no gainsaying that the speed of the wind determines the amount of dust that is seasonally or annually brought into the region. Therefore, assessing the rate at which this climatic parameter moves across the study area during Harmattan season will go a long way in making sense out of the spatial variations of the season in last three decades. The spatial variations and distributions of wind speed in Northeastern Nigeria can be seen in the six sub periods in (Fig. 1.9 to 1.14 ).

The sub period of wind speed distribution for 1984/1985 - 1988/1989 in (Fig. 1.9) shows variations between $2.27 \mathrm{kn}$ in south to $5.79 \mathrm{kn}$ in the north of the study area. Maiduguri shows the highest wind speed followed by areas around Nguru and Potiskum. Areas around Bauchi, Gombe and Yola in the south show relatively low wind speed in this sub period.

The sub periods of wind speed variations and distributions for 1989/1990 - 1993/1994 and 1994/1995 - 1998/1999 in (Fig. 10 and 11) show similar variations and distribution patterns. The variations in (Fig. 10) and (Fig. 11) cover between $1.98 \mathrm{kn}-8.78 \mathrm{kn}$ and $1.79 \mathrm{kn}-7.40 \mathrm{kn}$ respectively. Potiskum area in both the sub periods show the highest wind speed followed by 
Nguru and Maiduguri in the north. Areas around Bauchi, Gombe and Yola in both sub periods witnessed relatively low wind speed.

The sub period of wind speed variations and distributions for 1990/2000 - 2003/2004 in (Fig. 12) shows variation between $1.71 \mathrm{kn}$ in the south and $7.05 \mathrm{kn}$ in the north. Areas around Potiskum, Nguru and Gombe witnessed high wind speed while Bauchi and Yola in the south were low. The sub period of wind speed variations and distributions for 2004/2005 - 2008/2009 in (Fig. 1.13) shows variations between $2.71 \mathrm{kn}$ in south and $7.11 \mathrm{kn}$ in the north. Potiskum area shows high wind speed followed by Nguru, Maiduguri and Gombe. Bauchi and Yola areas show low.

The sub period for 2009/2010 - 2013/2014 in (Fig. 14) shows relatively high wind speed across the study area. It varies between $3.56 \mathrm{kn}$ in the south and $6.62 \mathrm{kn}$ in the north. Maiduguri areas witnessed high wind speed followed by Nguru, Potiskum and Gombe while Bauchi and Yola were low. It is important to know that the speed of the wind decreases as it moves southwards due to distance (latitudes) and friction generated by the earth-bound materials carried by the wind in the study area (Danlami, 2017). Moreover, the undulating plains in the Chad basin formation in Maiduguri and Potiskum are responsible for high speed of the wind experienced in the region. It is important to state here that wind speed tends to be higher in areas where there are no barriers like shelter belts and highlands.

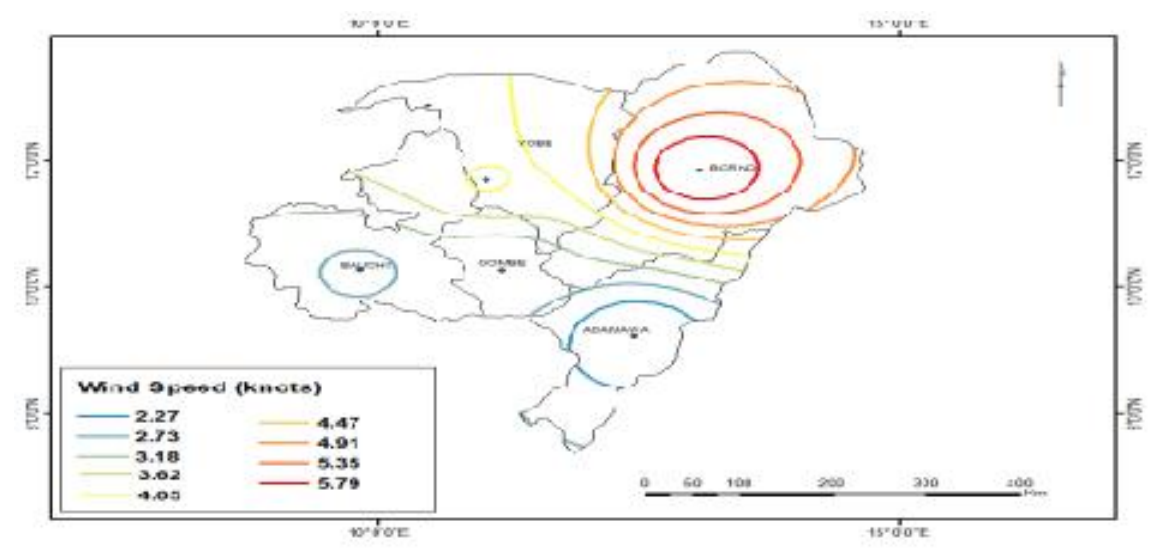

Figure 9. Spatial Wind Speed Distribution in Northeastern Nigeria (19984/1985 to1988/1989) 
Dantata Danlami, et al/ GEOSI Vol. 4 No. 2 (2019) 105-123

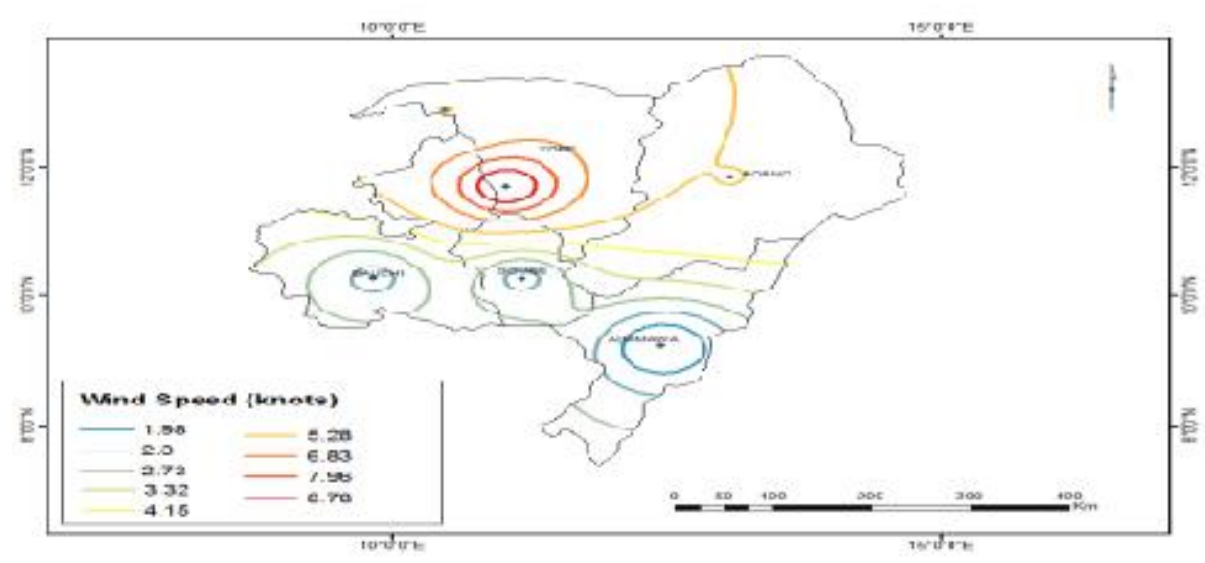

Figure 10. Spatial Wind Speed Distribution in Northeastern Nigeria (1989/1990 to1993/1994)

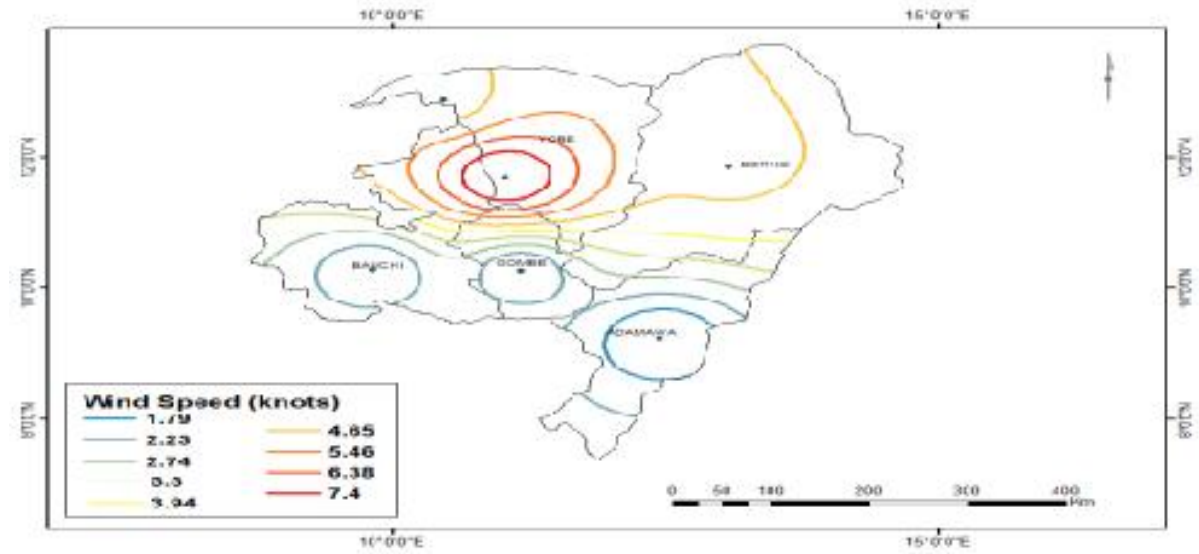

Figure 11. Spatial Wind Speed Distribution in Northeastern Nigeria (1994/1995 to 1998/1999)

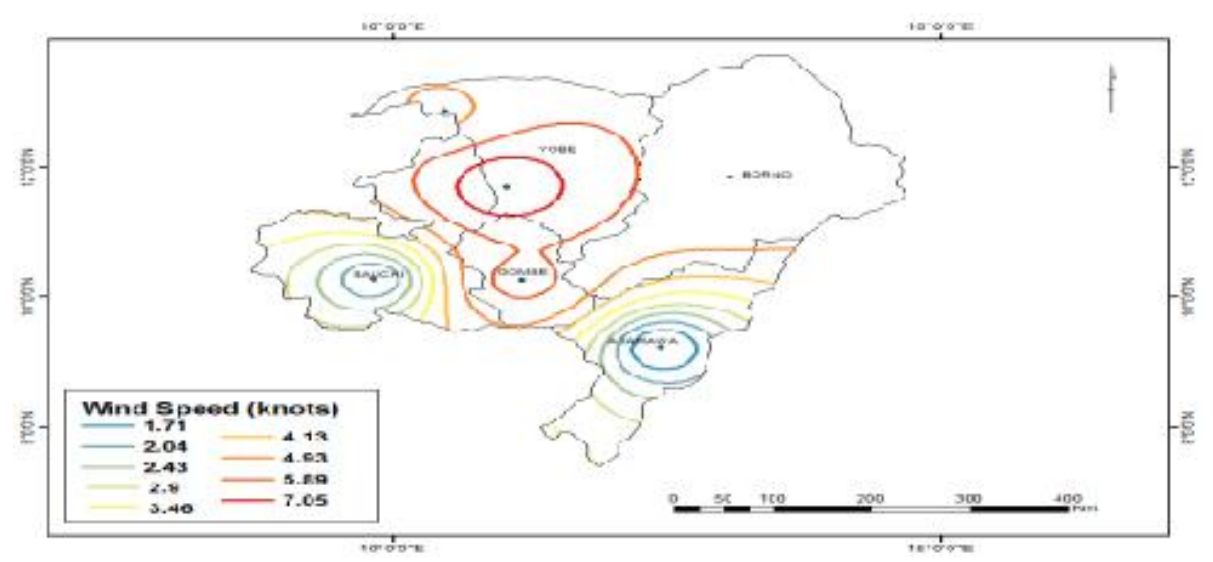

Figure 12. Spatial Wind Speed Distribution in Northeastern Nigeria (1999/2000 to2003/2004) 
Dantata Danlami, et al/ GEOSI Vol. 4 No. 2 (2019) 105-123

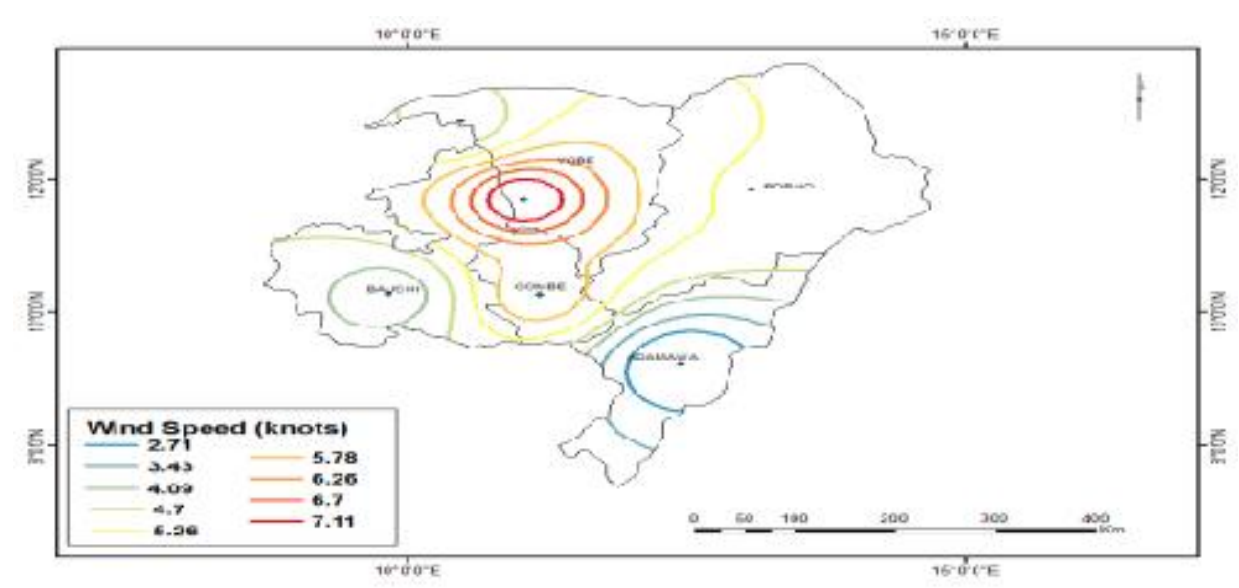

Figure 13. Spatial Wind Speed Distribution in Northeastern Nigeria (2004/2005 to 2008/2009

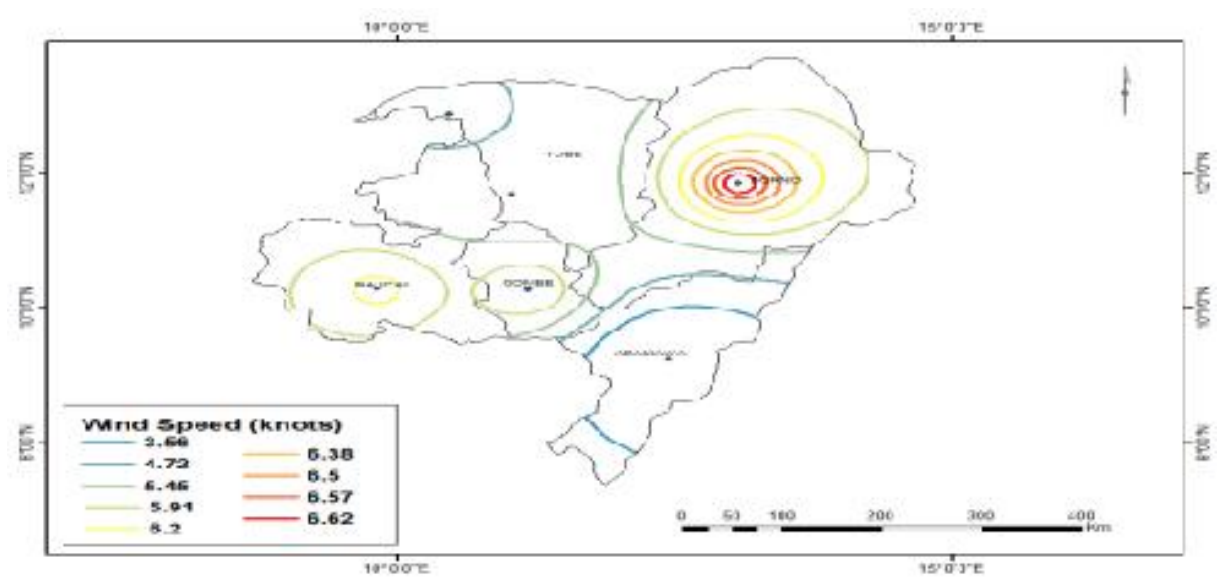

Figure 14. Spatial Wind Speed Distribution in Northeastern Nigeria (2009/2010 to 2013/2014)

From the above analysis, it is glaring that wind speed in the study area shows a regular distribution pattern in the last three decades. The speed of the wind increases northwards i.e. relatively low in the south and high in the north. This conforms to the work of (Adaramola and Oyewole 2011) where they reported that Wind Speed is low in Southern Nigeria and relatively high in the Northern parts of the country. The relief and other local factors in the study area could account for the variations and the distribution patterns of this climatic parameter across the region. It is important to note that Maiduguri and Potiskum have featured prominently as areas with high wind speed at one point or the other within the sub periods and this may not be 
unconnected with the influence of the easterlies wind in shifting the flow pattern of the northeast trade wind.

The spatial analysis of the wind speed in the last couple of decades has shown that it is on the rise which agrees with the temporal analysis. This sends a signal that the desert is vigorously advancing into the savannah belts of Nigeria because the northeast trade wind is responsible for the desert-like conditions in the Sudano-sahelian ecological zone of the study area. The spatial analysis also agrees with what (Dahuwa el at., 2018) where they reported that The wind speeds for Azare, Bauchi State, are high enough to support wind power generation in all strong wind regions of the country. The speed of the wind during the Harmattan season is seen to be stronger in the months of December and January and this conforms to what was reported by (Waewsak et al., 2011). They opined that wind speedanalysis showed strong and sufficient wind for power generation occurred during the months of January to July and in the month of October 2008 in Thasala district in the southern province of Thailand where the south east Asian Monsoon is experienced which is similar to West African Monsoon. Fagbenle et al., (1980) reported that average wind speed across Nigeria is about $3 \mathrm{~m} / \mathrm{s}$. In addition, they found that wind speeds are generally higher in the northern part of Nigeria than in the southern part of the country. Ojosu and Salawu (1990a) studied wind speed data from 1951-1975 from 22 stations across the country and they concluded that Sokoto area (in northern part) have highest wind speed of about $5.12 \mathrm{~m} / \mathrm{s}$ in June and annual average of $3.92 \mathrm{~m} / \mathrm{s}$

\section{Conclusion}

Wind speed is the principal climatic element that drives the Harmattan season in West African sub region. It drives the season by conveying huge amount of dust from the Sahara Desert particularly from the Bodele depression across the Northeastern Nigeria. The speed of the wind varied both temporally and spatially with latitude and some geographical factors playing significant role in bringing about the patterns of variations and their trends over the years i.e. it is higher in the North particularly around Maiduguri and Potiskum areas due to the plains of the chad basin formation and lower in the South due to some geographical factors such the Fika hills in the southern part of Potiskum and as well as the strategic location of the Biu plateau that separate the Chad basin formation to the North and the Benue trough to the South. 
Dantata Danlami, et al/ GEOSI Vol. 4 No. 2 (2019) 105-123

\section{Acknowledgement}

We wish to acknowledge the Nigerian Meteorological Agency (NIMET) for providing us with the data to carry out this climatic study.

\section{References}

Adaramola,M.S.andOyewola,O. M. (2011). Wind Speed Distribution and Characteristics in Nigeria. Asian Research Publishing Network (ARPN). Journal of Engineering and Applied Sciences.ISSN 1819-6608.www.arpnjournals.com

Amadi, S. O., Udo, S. O. and Ewona, I. O. (2014). Trends in Monthly Mean Minimum and Maximum Temperature Data over Nigeria for the Period 1950-2012. International Research Journal of Pure and Applied Physics, 2(4), 1-27.

Ayoade, J.O. (2004). Introduction to Climatology for the Tropics. $2^{\text {nd }}$ ed. Spectrum Books Limitted, Spectrum House Ring Road Ibadan, Nigeria.

Balarabe, M., Abdallah, K., and Nawawi, M. (2015). Long- Term Trend and Seasonal Variability of Horizontal Visibility in Nigerian Troposphere.Journal of Atmosphere 6:1462-1486; doi:10.3390/atmos6101462.

Dahuwa, D., Promise, K. U., Umar, W., Bello, I. and Mohammed, R. (2018). Analysis of Wind Speed And Frequency InAzare North eastern Part of Nigeria. IOSR Journal of Applied Physics (IOSR-JAP) e-ISSN: 2278-4861.Volume 10, Issue 1 Ver. I. PP 09-17 www.iosrjournals.org DOI: 10.9790/4861-1001010917 www.iosrjournals.org

Danlami, D., Gwari, M., Suleiman, S., and Bara, A. (2018). Temporal and Spatial variations of Groung Surface visibility during Harmattan Season in North-Eastern Nigeria.Ceylon Journal Science, 47(4), 337 - 346. DOI: http://doi.org/10.4038/cjs.v47i4.7551.

Danlami, D. (2017). Spatio-Temporal Variations of Harmattan Season in Northeastern Nigeria.M.Sc. Dissertation (Not published) Submitted to the Department of Geography, Bayero University, Kano, Nigeria.

De Longueville, F., Hountondji, Y. C., Henry, S. and Ozer, P. (2010). What do we Know about the Effects of Desert Dust on Air Quality and Human Health in West Africa compared to other regions? Journal: Science of Total Environment

Fagbenle, R.L., Fasade, A.O., Amuludun A.K. andLala,P.O.( 1980). Wind power potentials of Nigeria. 12th Biennial conference of the West African Science Association, University of Ife, Nigeria.

Getis, A., Getis, J., Bjelland, M. and Fellmann, J.D. (2011).Introduction to Geography. $13^{\text {th }}$ ed. The McGraw-Hill Companies, Inc., 1221 Avenue of the Americas, NY10020. 
Dantata Danlami, et al/ GEOSI Vol. 4 No. 2 (2019) 105-123

Karabulut, M., Demirci, A. and Kora, F. (2012). Analysis of spatially distributed annual, seasonal and monthly temperatures in Istanbul from 1975 to 2006.World Applied Sciences Journal, 12(10), 1662-1675

Ojosu, J.O. and Salawu, R.I. (1990).An evaluation of wind energy potential as a power generation source in Nigeria.Solar \& Wind Technology.ELSEVIER.Volume 7, Issue 6, 1990, Pages 663-673

Schwanghart, W. and Schutt, B. (2007). Meteorological causes of Harmattan dust in West Africa. Journal of Science Direct Geomorphology.

Shuman, M. (2007) Evaluation of five GIS basedInterpolation techniques for estimating the Radonconcentration for unmeasured zip codes in thestate of Ohio, Master of Science Degree in Civil Engineering, University of Toledo, 28-29 Pp.

Waewsak, J., Chancham, C., Landry, M. and Gagnon, Y (2011).An Analysis of Wind Speed Distribution at Thasala, Nakhon Si Thammarat, Thailand.Journal of Sustainable Energy \& Environment 2 pp 51-55

Willmott, C., Robeson, S. and Philpot, W. (1985). Small- scale climate maps: A sensitivity analysisof some common assumptions associated withgrid-point interpolation and contouring. American Cartographer 12(1):5-16. 